\title{
Static Thrust Measurement for Propeller-driven Light Aircraft
}

\author{
Chen Mingtai \\ Shanghai Aircraft Design and Research Institute \\ Shanghai, China \\ chenmingtai@comac.cc
}

\begin{abstract}
Since in-flight thrust is a calculation based upon a number of separate measurements. Only on the ground, either in an engine cell or during a static thrust run, do we actually measure thrust using load cells. In this thesis a device was devised to measure the static thrust of propeller-driven light aircraft. Also a static thrust model of propeller-driven light aircraft was established to compare with test results. Three propeller-driven light aircrafts were tested with different diameters of propeller. The propellers of all three aircrafts were connected to engine shaft directly without gear box between the propeller and engine shaft so that propeller revolution speed was regarded to equal to engine revolution speed (RPM).
\end{abstract}

Keywords- In flight thrust, Load cell, Static thrust, Propeller revolution speed, Engine RPM

\section{INTRODUCTION}

Broadly speaking, airplane propulsion system can be classified into four categories:

- Piston engines;

- Jet engines;

- Rocket engines;

- Electric motors.

The prevailing types of engines used in airplanes are: piston engines, turbojets, turbofans and turboprops. Here I discuss propeller-driven piston engines only because the aim of the thesis is to measure static thrust of propeller-driven light aircrafts.

From the definition of horsepower, the equation for thrust horsepower in terms of thrust and true airspeed is as follows:

$$
\begin{aligned}
& T H P=\frac{F_{n} \cdot V_{t}}{550} \text { (where Vt has units of feet/second) } \\
& F_{n}=\frac{550 . T H P}{V_{t}}
\end{aligned}
$$

Equation 2 cannot be used at zero speed. For takeoff performance, the static thrust could be measured on a thrust stand. Then at speeds around lift-off, equation 2 could be used. A thrust model might be just a linear interpolation of the thrust stand value and the lift-off value versus speed.

\section{IMPORTANCE OF STATIC THRUST}

First, before airborne flight tests a new aircraft driven by piston engine should be conducted taxiing tests at low speed and high speed. After static thrust of the aircraft has been determined from "idle" to "full throttle" at different temperatures, the confidence would be built up when the aircraft is conducted low speed taxiing test at "idle" position and high speed taxiing test at "full throttle" position. Second, a thrust model could be established through static thrust data to estimate takeoff distance and time and landing distance and time which could make a comparison with measurement data to verify whether the data are satisfactory or not and provide confidence to test method and accuracy.

\section{EXPERIMENTAL APPARATUS}

\section{A. Measurement System Overview}

The measurement system developed here can be divided into three subparts, namely, the Load Cell, the Adjustable Platform and the cable and strips which are shown in the schematic in Figure 1 and discussed below. The aircraft stands on an even concrete ground. Then tie the strips around the undercarriages, the struts connecting the fuselage and the wing (if available) and the wings (if it is necessary). Adjust the platform vertically to keep the cable level by measuring the heights of its ends above the ground. Measure the incidence angle between thrust line and horizontal line. If this incidence angle is less than 5 degrees, it is assumed that static thrust equals to measurement data. If this incidence angle is more than 5 degrees, static thrust equals to measurement data divided by $\cos (\theta)$ ( $\theta$ is the incidence angle between thrust line and horizontal line).

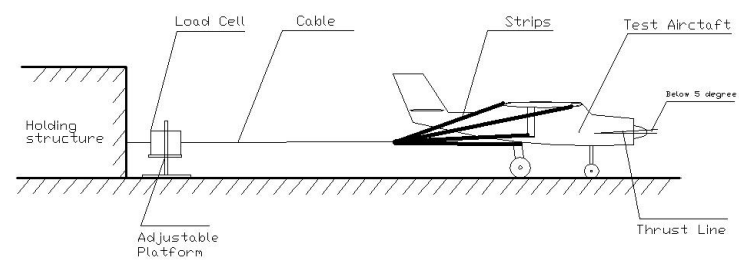

Figure 1. Measurement system schematic overview

\section{B. Load Cell}

The ring of the load cell is tied to a fixing structure. The hook of the load cell is connected to the cable. The load cell is capable of measuring up to $5000 \mathrm{Kg}$ in thrust with a rated output accuracy of $2 \mathrm{Kg}$ (full scale). Its specifications and functions are listed as follows: 
1)Model: Crane Scale (UT-A-5T)

2)Specification:

\begin{tabular}{|l|l|l|l|l|l|l|}
\hline Capacity & $\mathbf{6 0 0 K g}$ & $\mathbf{1 T}$ & $\mathbf{1 . 5 T}$ & $\mathbf{2 T}$ & $\mathbf{3 T}$ & $\mathbf{5 T}$ \\
\hline Division & $0.2 \mathrm{Kg}$ & $\begin{array}{l}0.5 \mathrm{~K} \\
\mathrm{~g}\end{array}$ & $0.5 \mathrm{Kg}$ & $1 \mathrm{Kg}$ & $1 \mathrm{Kg}$ & $2 \mathrm{Kg}$ \\
\hline $\begin{array}{l}\text { Power } \\
\text { Source }\end{array}$ & \multicolumn{7}{|c|}{ AC: $110 / 220 \mathrm{~V}$, DC: $6 \mathrm{~V}$} \\
\hline
\end{tabular}

Function keys:

\begin{tabular}{|l|l|}
\hline On/Off & Turns instrument On or Off. \\
\hline CHANGE & Select the needed division. \\
\hline LOCK & To keep the value of weigh in the display. \\
\hline ZERO & Reduce gross weight on pan as tare weight. \\
\hline
\end{tabular}

Lamp indicator:

\begin{tabular}{|l|l|}
\hline MOTION & It means unstable. \\
\hline HOLD & It means the value of weigh is locked \\
\hline
\end{tabular}

C. Aircraft Selection

1) Jabiru(ZU-DAX). The Jabiru is Australian designed and manufactured using Fibre Reinforced Plastic (FRP) technologies. The Jabiru aircraft is powered by a Jabiru 4 cylinder 4 stroke $2200 \mathrm{cc}$ air cooled engine. The propeller model of Jabiru (ZU-DAX) is C000242-D60P42.

2)Cessna150(ZS-NAL). The Cessna 150 is a two-seat tricycle gear general aviation airplane, originally designed for flight training. The Cessna150 (ZS-NAL) is powered by the Continental O-200-A $100 \mathrm{hp}(75 \mathrm{~kW})$ engine. The propeller model of Cessna150 (ZS-NAL) is McCauley 1A102/OCM.

3)Cessna172(ZS-MWL). The Cessna 172 is the most successful mass produced light aircraft in history. The Cessna172 (ZS-MWL) is powered by the Lycoming O-320E2D $150 \mathrm{hp}(110 \mathrm{~kW})$ engine. The propeller model of Cessna172 (ZS-MWL) is McCauley 1C160/CTM 7553.

\section{EXPERIMENTAL PROCEDURE}

\section{A. $\quad$ Test Procedure}

Conduct the tests in the early morning when it is relatively cold. Start the engine for warm-up, collect data from idle to full throttle in equally spaced RPM increment, then go back from full throttle to idle in same RPM decrement. Each test point should stabilize for 30 seconds. Record wind velocity, wind direction, ambient temperature, ambient pressure, RPM, MAP (if it is displayed in the cockpit) and load cell reading.

After collecting that data in early morning, proceed to shut the aircraft engine down and wait. Refuel if necessary. After the temperature increase some by late morning, repeat the whole procedure. Finally, do the process a third time in the afternoon. This will give you a range of ambient temperatures.

\section{B. Uncertainty and Sensitivity Analysis}

Due to the quantified accuracy depends on each individual test point, their values have been provided at static thrust of $200 \mathrm{~kg}$ as follows:

Incidence angle includes the incidence angle of cable, ground slope and thrust incidence angle which the maximum value neglected is 5 degrees. If the thrust incidence angle is more than 5 degrees, this angle will be corrected.

\section{Propeller Static Thrust Estimation Model}

The static thrust estimation model of propeller is obtained from lab test and represented as followed:

$$
T_{s}=1.283 \times 10^{-12} \times R P M^{2} \times D^{4} \times \rho \times K_{t}
$$

Ts=Propeller Static Thrust, $\mathrm{Kg}$ Minute

RPM =Propeller revolution speed, Revolution Per

$\mathrm{D}=$ Propeller Diameter, Inches

$\rho=$ Air Density, $\mathrm{Kg} / \mathrm{m} 3$

$\mathrm{Kt}=$ static thrust coefficient, approximate 0.73 .

\section{RESUlts AND DisCUSSION}

\section{A. Test Results}

Three aircrafts stated in the goals had been tested, and a number of runs had been completed from "idle" position to "full throttle" position. The static thrust plots of three aircrafts are shown in Figures 2, 3 and 4 as followed:

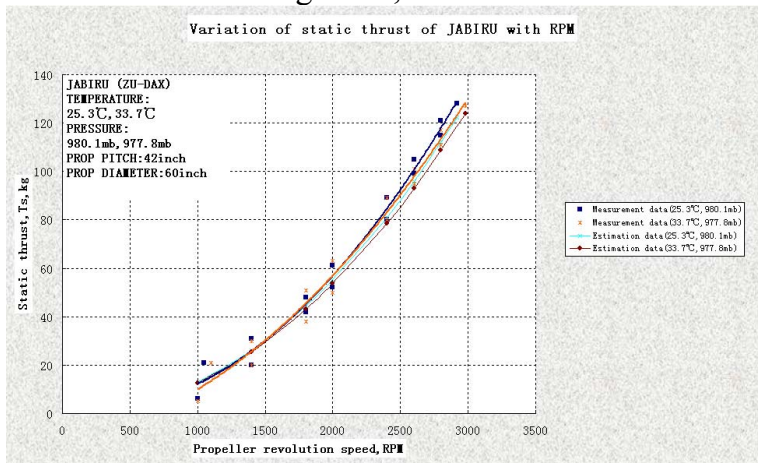

Figure 2. Static thrust of Jabiru (ZU-DAX)

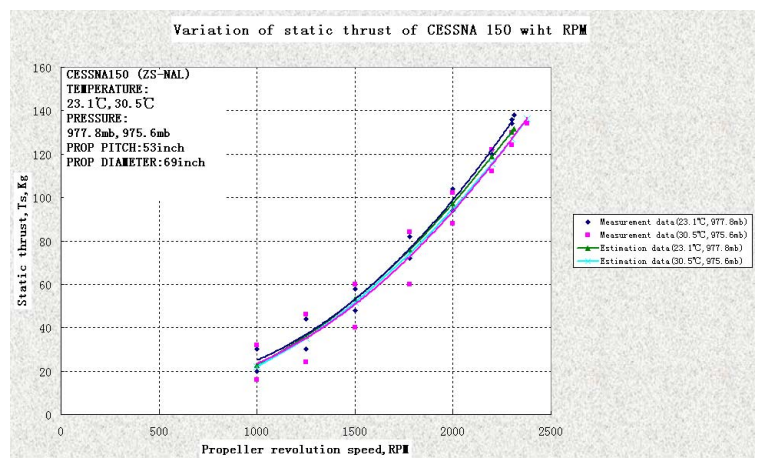

Figure 3. Static thrust of Cessna150 (ZS-NAL) 


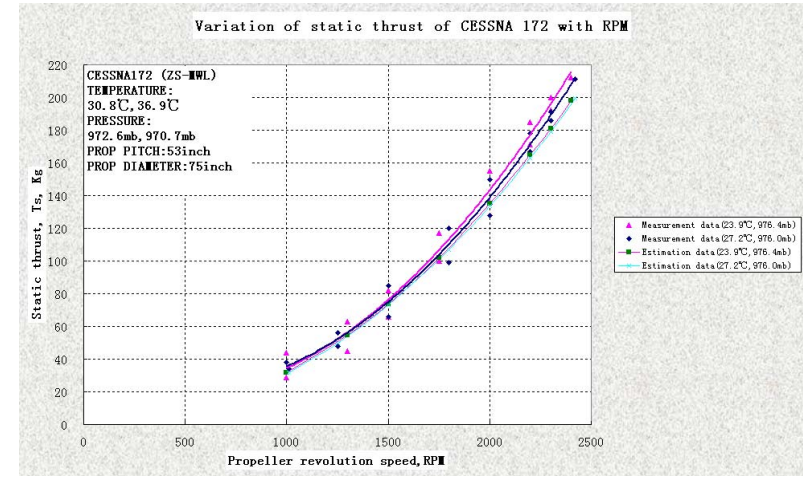

Figure 4. Static thrust of Cessna172 (ZS-MWL)

\section{B. Observation and Discussion}

The static thrusts of three aircrafts were fitted in a second order curve. For Jabiru (ZU-DAX) the static thrust was ranged from $12.5 \mathrm{Kg}$ at "idle" position to $127 \mathrm{Kg}$ at "full throttle" position. For Cessna150 (ZS-NAL) the static thrust was ranged from $22 \mathrm{Kg}$ at "idle" position to $136 \mathrm{Kg}$ at "full throttle" position. For Cessna172 (ZS-MWL) the static thrust was ranged from $32 \mathrm{Kg}$ at "idle" position to $211 \mathrm{Kg}$ at "full throttle" position. The diameters of propeller of the above aircrafts increased gradually which meant the bigger the propeller was the more the static thrust produced at the same RPM. So the results were complied with the theory and were confirmed by propeller static thrust estimation model.

Since ambient pressure at test ground differed slightly for different test days, it can be assumed that ambient pressure had no influence on static thrust at the same airport elevation. The measurement data were the same as the estimation data at "idle" position, but at "full throttle" position the measurement data were higher than the estimation data which were acceptable because the model did not consider additional fact (ground clearance) and ground effect could change the angle of attack of the propeller blades relative to the flow. At relatively low RPM, the temperature did not affect the static thrust obviously. At "full throttle" position the temperature' effect could be observed. The maximum wind was 8.8 knots which was tested on Cessna150 (ZS$\mathrm{NAL})$ at $30.5^{\circ} \mathrm{C}$ and the result was fitted with the model data.

TABLE I. INSTRUMENTATION ACCURACY AT A GLANCE

\begin{tabular}{|l|l|l|l|}
\hline Instrument & Measured Quantity & Unit & $\begin{array}{l}\text { Accuracy@ 200 } \\
\text { kg }\end{array}$ \\
\hline Load Cell & Static Thrust & $\mathrm{Kg}$ & $\pm 0.5 \%$ \\
\hline Trigonometry & ncidence angle & Degree & $\pm 0.38 \%$ \\
\hline
\end{tabular}

Another observation was static thrust decreased with ambient temperature increasing at same RPM which was practical. However propeller revolution speed increased with temperature increasing slightly at "full throttle" position where static thrusts were almost equal with temperatures increasing which might caused by air density decreasing while increasing mixture ratio slightly which improved engine efficiency and RPM increment could compensate to density loss.

\section{CONCLUSIONS}

The results from all the tests performed so far have been very encouraging. All expectations from this experiment have been surpassed and the following conclusions have been drawn on the results obtained and the observations made herein.

The results of static thrust experiments conducted have been successfully repeated and matched to estimation data.

Use test procedure described in Chapter 4.1 to conduct the test which does not need to measure static friction between test ground and the aircraft since it is hard to measure static friction.

The maximum wind was 8.8 knots during the test which gave a good result. So far it can conclude that 8.8 knots wind has no effect in determining static thrust.

The static thrust of an aircraft increases with the diameter of a propeller increasing. The trend of static thrust increment from "idle" to "full throttle" is a second order curve.

The propeller revolution speed increases with ambient temperature increasing at "full throttle" position. The static thrusts at "idle" and "full throttle" position are almost same for different temperatures.

Thus it can be concluded that the primary goal of this effort has been successfully accomplished and expectations been exceeded.

\section{RECOMMENDATIONS}

Substantial amount of time and effort has been spent in the development of this apparatus and the experimental procedure. However, a few recommendations that can further improve this system are:

Incorporate automatic data acquisition. This would help further measure static thrust of an aircraft driven by a powerful engine. Because it is difficult to stand behind the slipstream of the propeller and record the data. This also would improve the accuracy of the system due to eliminate human error.

Determine wind effect. This could take a long time to wait for a range of wind speed. To date the maximum wind was 8.8 knots which had no effect on measuring static thrust. It hopes further tests could discover how much the wind affects static thrust.

As far as the experiments are concerned, this system can be used with little or no modifications to measure static thrust of a range of propeller-driven light aircraft.

\section{REFERENCES}

[1] Walter S. Diehl: "Static Thrust of Airplane Propellers". T. R. No.447, N.A.C.A., 1934.

[2] Durand, W. F., and Lesley, E. P.: Experimental Research on Air Propellers-II. T. R. No.30, N.A.C.A., 1920.

[3] Wayne M. Olson: Aircraft Performance Flight Testing, Technical Information Handbook, 2000.

[4] Weick, Fred E.: Full Scale Wind-Tunnel Tests of a Series of Metal Propellers on Ave-7 Airplane. T. R. No.306, N.A.C.A., 1929. 